\title{
Does rock chemistry affect periphyton accrual in streams?
}

\author{
Elizabeth A. Bergey
}

Received: 16 December 2007/Revised: 20 May 2008/Accepted: 29 May 2008/Published online: 28 June 2008

(C) Springer Science+Business Media B.V. 2008

\begin{abstract}
Stones of different rock types often accrue different amounts of periphytic algae. Although algal biomass may be positively related to stone roughness, the confounding role of rock chemistry is unclear. This independent effect of rock chemistry on benthic algae was tested using the nutrient-diffusing technique, by incorporating powdered stone, rather than nutrients, into the agar matrix. Rocks tested were sandstone, obsidian, schist, greywacke, pumice, gypsum, limestone, serpentine, and phosphorite. Petri-dishes containing powdered rock and agar, and covered with a permeable cellulose filter, were incubated in eight pools in a granitic stream. Algal biomass did not differ among any of the nine rock types and plain agar control, whereas biomass differed among the concurrently placed nutrient diffusing substrates (the stream was phosphorus-limited). Algal composition was more related to an upstream-downstream gradient (for filamentous algae) and pool-specific effects (deposition of fine sediment for diatoms) than rock chemistry. This minimal effect of rock chemistry may be caused by the low dissolution rate of stones.
\end{abstract}

Handling editor: J. Padisak

E. A. Bergey $(\bowtie)$

Oklahoma Biological Survey and Department of Zoology, University of Oklahoma, Norman, OK 73019, USA

e-mail: lbergey@ou.edu
Keywords Benthic algae - Epilithic algae · Substrate texture $\cdot$ Nutrient diffusing substrates . Bedrock

\section{Introduction}

Benthic and periphytic algae are, by definition, closely associated with their substrates. The nature of substrates varies widely and algal-supporting hard substrates in freshwaters commonly include rocks, macrophytes, and woody debris.

Benthic substrates often provide more than an inert surface; physical and chemical substrate characteristics may influence algal assemblage composition and biomass. Thus, the physical structure of floating leaved macrophytes may shade epiphytic algae (Cattaneo et al., 1998; Laugaste \& Reunanen, 2005). Chemically, some macrophytes produce alleochemicals that reduce epiphytes (Wu et al., 2007) and algae and macrophytes both secrete and absorb a variety of compounds (e.g., silica: Jorgensen, 1957).

Stones in streams provide a three-dimensional physical habitat for periphytic algae. Algal biomass is affected by stone location in streams (Matthaei et al., 2003) and algal biomass generally increases with stone size (Ledger and Hildrew, 1998). At the scale of individual stones, orientation and exposure to stream flow affect algal biomass accumulation 
(Stevenson, 1984). Stone type also matters; stone roughness and porosity increase algal biomass by providing roughness features (e.g., depressions, crevices, and pore spaces; Sanson et al., 1995) that protect algae from grazing and other disturbances (Bergey, 2005).

In contrast to these physical effects of stones on periphytic algae, the influence of stone chemistry is unclear (Burkholder, 1996). Stones of different rock types may accrue the same amount of algae or there may be differences in algal accrual patterns among rocks types, especially during early colonization (Whitton, 1975; Blinn et al., 1980). In the analogous situation on land, soils of different parent rock types sometimes support different vegetation assemblages. This is particularly true of non-silica-based rocks, such as gypsum (Campbell \& Campbell, 1938), which is based on $\mathrm{CaSO}_{4}$, and serpentine (Kruckeberg, 1954), which has a different $\mathrm{Ca}$ and $\mathrm{Mg}$ ratio from most other rock types. Projecting from the terrestrial analog, it seems likely that rock chemistry would influence periphyton assemblages in streams, especially because benthic algae can be physically located next to stones.

Because both rock roughness and surface chemistry vary with rock type, it is a challenge to determine whether differences in periphyton among rock types result from rock roughness, chemistry, or both. I investigated the role of rock chemistry alone in algal biomass accrual and assemblage composition by using a nutrient diffusing substrate technique, but incorporating powdered rock instead of nutrients in the agar matrix. Powdering the rocks removed any roughness effects. The rocks tested comprised a silica-based series: sandstone, obsidian, schist, greywacke, and pumice; and a non-silica series: gypsum, limestone, serpentine, and phosphorite.

\section{Methods}

The effect of rock chemistry on benthic algal growth was tested by grinding stones, incorporating the ground stone into agar in Petri dishes, and testing algal growth on cellulose papers covering the agar. Substrates were colonized in a stream and both algal biomass and taxonomic composition were evaluated.

Nine types of rocks were tested. Most of the rocks were purchased from a minerals supply company (D. J. Minerals, Butte, MT); one was collected locally in Oklahoma (Table 1). Many of the rocks were silica-dominated (greywacke, obsidian, pumice, sandstone, and shale). Four non-silica dominated rock types were included: gypsum is a mineral containing a high sulphur content, limestone is biologically produced calcium carbonate that settled in oceans, phosphorite (=rock phosphorus) is a rock with a high phosphorous content, and serpentine is a magnesium iron silicate that may include chromium or other chemicals.

Large rocks were reduced with a hydraulic rock splitter and the resultant smaller rocks were powdered by processing with a rock crusher and then a rock grinder. Instruments were cleaned between processing different rock types. Plastic Petri dish bottoms of $5 \mathrm{~cm}$ diameter were filled with $15 \mathrm{~g}$ of powdered
Table 1 Rocks tested in agar-rock diffusing substrates. Approximate roughness values are from Bergey (2006)

NA, Not available

\begin{tabular}{llll}
\hline $\begin{array}{l}\text { Rock } \\
\text { type }\end{array}$ & $\begin{array}{l}\text { Rock } \\
\text { classification }\end{array}$ & $\begin{array}{l}\text { State of } \\
\text { origin }\end{array}$ & $\begin{array}{l}\text { Approximate } \\
\text { roughness }\end{array}$ \\
\hline Sandstone & Sedimentary & Montana & $1.51,2.84$ \\
Greywacke & Sedimentary & Montana & 0.71 \\
Schist & Metamorphic & Montana & 1.30 \\
Pumice & Igneous & Oregon & 10.94 \\
Obsidian & Igneous & Oregon & NA \\
Gypsum & Sedimentary & Utah & 0.87 \\
Limestone & Sedimentary & Oklahoma & 4.37 \\
Phosphorite & Sedimentary & Montana & NA \\
Serpentine & Metamorphic & Oregon & NA \\
\hline
\end{tabular}


rock or $7.5 \mathrm{~g}$ of the less dense pumice, which filled approximately $2 / 3$ of the Petri dish. A $2 \%$ agar solution was added to fill each dish and the hot agarrock mixture was gently stirred to release entrapped air bubbles. In addition to the nine rock types, a tenth treatment of plain agar served as a control. Petri dishes were covered and refrigerated overnight before the start of the experiment.

The experiment was arranged on $30-\mathrm{cm}$ square concrete paving stones. Empty Petri dishes were glued onto the paving stones using epoxy glue. Downstream drift of any released chemicals was minimized by arranging seven substrates on the front edges of each diagonally placed paving stone; the remaining three Petri dishes were positioned across the paving stones near the downstream point. The rock-agar treatments were arranged randomly within each of eight replicate paving stones.

Prior to deployment, agar substrates were removed from their original Petri dishes, flipped over, and transferred to the Petri dishes that were glued to the paving stones. Because the powdered stone settled in the agar solution, flipping the agar discs exposed a high concentration of rock on the upper surface. Agar plates were covered with discs of permeable cellulose paper (=filter), which were held in place by rubber bands and which provided easily harvested surfaces for algal growth. This procedure was similar to the design by Pringle (1990), who mixed sand and nutrients with agar in Petri dishes.

An additional paving stone held nutrient-augmented agar substrates: agar with added nitrogen $(\mathrm{N}$; as $0.1 \mathrm{M} \mathrm{NaNO}$ ), phosphorous $(\mathrm{P}$; as $0.1 \mathrm{M}$ $\left.\mathrm{KH}_{2} \mathrm{PO}_{4}\right), \mathrm{N}+\mathrm{P}$, and an agar control. Like the powdered stone treatments, nutrient dishes were covered with filters. Nutrient treatments were replicated twice on a single paving stone.

Rock Creek, the field site, is a second order stream located in the Arbuckle Mountains in south-central Oklahoma. The stream runs through an area where the underlying granite dome is exposed amidst the predominant limestone. The stream has eroded granite bedrock riffles/runs and coarse-sand pools. During the experiment, conductivity of the stream water averaged $430 \mu \mathrm{S}$ and $\mathrm{pH}$ ranged from 7.7 to 8.3.

On 20 August 2004, paving stones were placed in sequential pools over approximately $1 \mathrm{~km}$ of stream length. The upper site was below a small breeched dam and the lowest site was just downstream of a low water crossing used for farm vehicles and cattle. The nutrient-treatment paver was placed in the upstreammost pool. Paving stones and samples were retrieved two weeks later on 3 September. The harvest date was determined by an approaching storm. An earlier run of the experiment was destroyed by a spate. Decreasing water level over the two weeks beached one paver and three samples in another paver were lost in a cow print.

Water velocity was measured approximately $2 \mathrm{~cm}$ above the center of each paving stone at the start and end of the experiment with a Flo-Mate meter (HACH/ Marsh-McBirney, Frederick, Maryland). Shade was estimated as the percent of cover by riparian vegetation over the paver in each pool.

At harvest, the filters were trimmed to the area covering the agar, cut in half, and the halves were foil-wrapped and randomly assigned to chlorophyll $a$ analysis or algal identification. Samples were iced in the field and frozen upon return to the laboratory.

Chlorophyll $a$ concentration was used as a measure of algal biomass. Chlorophyll $a$ was extracted from filters using the ethanol extraction method of Sartory \& Grobbelaar (1984). Absorbance was measured using a Beckman Coulter DU350 spectrophotometer. The area of each extracted filter was determined by cutting out and weighing a photocopy of the filter and converting weight to area using the density of the photocopy paper.

Filamentous algae were assessed by vigorously shaking the filters in a $20-\mathrm{ml}$ scintillation vial and examining a pipetted sample in a wet mount at $400 \times$ magnification with an Olympus $\mathrm{BH} 2$ microscope. Separate, fresh algal samples from the site were examined directly after the experiment to determine the range of filamentous taxa present, especially for the Zygnematales, whose chloroplasts may condense when frozen. After ranking the filamentous algal taxa (described in the next paragraph), scintillation samples, still containing the filter were allowed to settle and the water was pipetted off and replaced with $30 \%$ hydrogen peroxide. Open vials were covered with a sheet of paper and allowed to sit for two weeks. The hydrogen peroxide removed diatoms from the filter, cleared the diatoms and oxidized the other organic matter (including the filamentous algae). The filter was removed and the samples rinsed by repeated settling, pipetting off most of the fluid, and adding distilled water. Subsamples were dried onto 
coverslips, mounted with Naphrax mounting medium, and viewed at $1,000 \times$.

Both diatoms and filamentous algae compositions were assessed using a relative abundance technique (Biggs, 1995) on samples from four of the eight pools (i.e., pools 1, 2, 3, and 8 were randomly selected). Samples from pool 7 were used to replace missing samples from the assessed pools. Each species was ranked on a relative scale of 1 (small and rare) to 7 or 8 (abundant and highest biomass). Both species density and cell biovolume are used in scoring; hence, relative abundance scores reflect the relative total biovolumes of the taxa.

Chlorophyll data were analyzed using ANOVA and Tukey's test (Statview, Version 5.0.1, SAS Institute, Cary, NC). The compositions of filamentous algal and diatom assemblages were compared using non-metric multidimensional scaling (NMDS) based on Bray-Curtis similarity, two-way analysis of similarity (ANOSIM2), and similarity percentages (SIMPER) (PRIMER, Version 5; PRIMER-E Ltd, Plymouth, UK). SIMPER was used to determine algal taxa that accounted for differences among assemblages, and relative abundance ranks were used to describe the differences.

\section{Results}

\section{Algal biomass}

After two weeks in Rock Creek, agar substrates resembled streambed substrates - both were covered by a brownish biofilm that included flocculent material and filamentous algae. There was no discernable difference in the appearance of the biofilm among the powdered rock treatments. In contrast, differences were apparent among the nutrient treatments, with greater growth on phosphoruscontaining substrates.

Algal biomass results were consistent with field observations. Chlorophyll concentrations among the powdered stone treatments, whether in the silica series or the miscellaneous chemistry series, were not significantly different from each other or from the agar control (two-way ANOVA; $F_{9,48}=1.37$, $P=0.227$; Fig. 1). In contrast to the powdered stone treatments, algal biomass was over twofold higher on phosphorous-enriched than non-phosphorous enriched
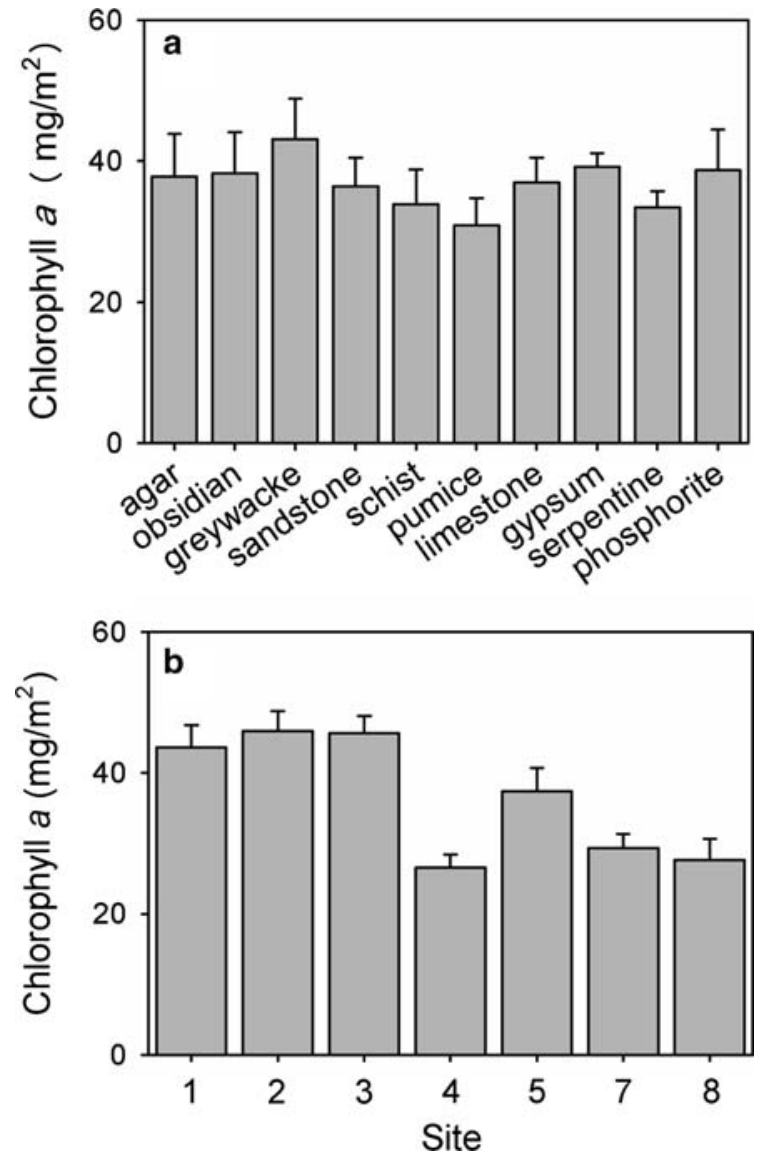

Fig. 1 Chlorophyll concentration (algal biomass) of filters from agar and agar-powdered rock substrates, arranged by (a) rock treatment $(n=7)$ and (b) location from upstream at pool 1 to downstream at pool $8(N=10)$. Error bars are $+1 \mathrm{SE}$

substrates (one-way ANOVA; $F_{3,4}=52.11$, $P=0.0012$; Fig. 2). Although not statistically significant (Tukey test, $P>0.05$ ), nitrogen addition increased chlorophyll $a$ concentration of both plain agar and phosphorous-enriched substrates by about $20 \mathrm{mg} / \mathrm{m}^{2}$. This additive effect of nitrogen might have been significant if there were more than two replicates.

Algal biomass was spatially different among pool sites (two-way ANOVA; $F_{6,48}=11.45, P<0.0001$; Fig. 1). The three upstream pools accrued more algae than three of the four downstream pools (Tukey's test; $P \leq 0.05)$. Pool characteristics included a range of percent shade and water depth, whereas water velocity was low at all sites (Table 2). No relationship was found between algal biomass and shade, depth, and water velocity (multiple regression; 


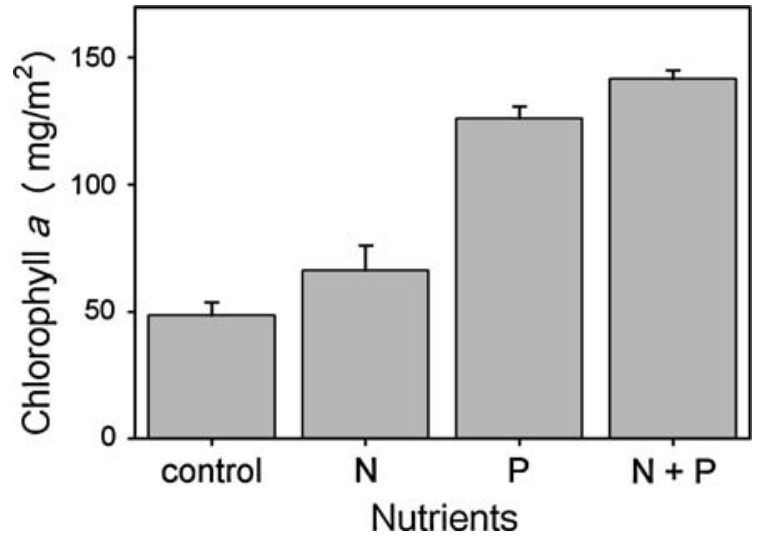

Fig. 2 Chlorophyll concentration of filters from nutrientdiffusing agar substrates located in pool $1(n=2)$. Control = plain agar, $\mathrm{N}=$ plus nitrogen, $\mathrm{P}=$ plus phosphorus, $\mathrm{N}+\mathrm{P}=$ plus nitrogen and phosphorus. Error bars are $+1 \mathrm{SE}$

Table 2 Characteristics of the eight studied pools in rock creek

\begin{tabular}{llll}
\hline $\begin{array}{l}\text { Pool } \\
\text { number }\end{array}$ & $\begin{array}{l}\text { Water velocity } \\
(\mathrm{m} / \mathrm{s})\end{array}$ & $\begin{array}{l}\text { Water depth } \\
(\mathrm{cm})\end{array}$ & $\begin{array}{l}\text { Percent } \\
\text { shade }\end{array}$ \\
\hline 1 & neg/neg & $31.0 / 26.5$ & 10 \\
2 & $0.04 / 0.01$ & $20.5 / 16.0$ & 40 \\
3 & $0.01 /$ neg & $15.8 / 12.5$ & 60 \\
4 & neg/neg & $25.5 / 20.0$ & 25 \\
5 & $0.02 /$ neg & $23.0 / 19.0$ & 50 \\
6 & $0.02 /$ dry & $5.5 /$ dry & 70 \\
7 & neg/neg & $7.5 / 3.0$ & 50 \\
8 & $0.02 / 0.02$ & $16.0 / 15.0$ & 50 \\
\hline
\end{tabular}

Measurements were taken at the location of the substrates. Paired measurements are at the start/end of the experiment. neg, negligible, with velocity $<0.01 \mathrm{~m} / \mathrm{s}$

$\left.R^{2}=0.24, F_{3,6}=3.13, P=0.817\right)$. Higher upstream biomass may have resulted from altered nutrients because the residence and animal pens were located adjacent to the upper sites.

\section{Algal composition}

Diatom assemblage composition was not significantly different among the nine ground rock and control agar substrates (ANOSIM2; $R=-0.115, P=0.95$ ). This lack of difference among rock substrates is apparent in the multivariate plot (NMDS; Fig. 3). Although there is an apparent trend toward clustering of samples in some rock types, such as pumice and limestone, these
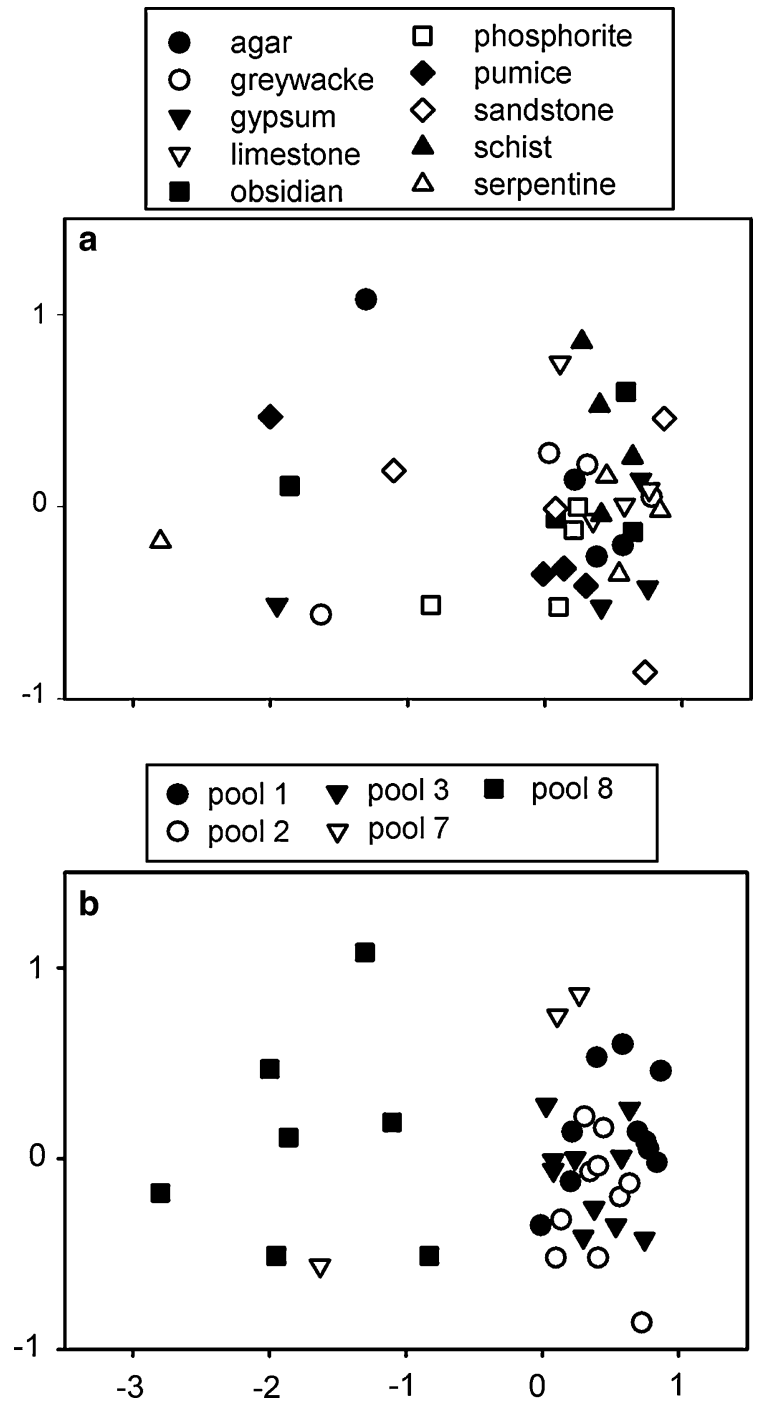

Fig. 3 Non-metric multidimensional scaling ordination of diatom assemblages from agar-powdered rock substrates. Assemblages are coded by rock type (a) and by pool location (b). Stress $=0.15$

sub-clusters were not distinct from assemblages on other rock types.

Diatom assemblages were dominated by benthic attached species at upstream sites and benthic motile species at the downstream-most site. The attached diatoms Gomphonema parvulum (Kütz.) Kütz., Nitzschia palea (Kütz.) W. Smith, and Synedra ulna (Nitzsch) Ehrenb. dominated in four of the five sites (Table 3; with diatom composition data (range of mean site ranks: 6.3-7.0, 5.5-6.0, 5.1-6.0, respectively). The most downstream site contained an 
Table 3 Dominant taxa of diatoms on substrates located in five pools

\begin{tabular}{|c|c|c|c|c|c|}
\hline Taxon & Pool 1 & Pool 2 & Pool 3 & Pool 7 & Pool 8 \\
\hline Gomphonema parvulum (Kütz.) Kütz. & 6.7 & 6.5 & 6.3 & 7.0 & 5.4 \\
\hline Nitzschia palea (Kütz.) W. Smith & 6.0 & 5.8 & 5.8 & 5.5 & 5.8 \\
\hline Synedra ulna (Nitz.) Ehrenb. & 5.7 & 5.1 & 5.3 & 6.0 & \\
\hline Nitzschia frustulum (Kütz.) Grunow & 5.0 & 4.9 & 5.1 & & \\
\hline Cymbella affinis Kütz. & 4.0 & 4.8 & 5.1 & & \\
\hline Navicula cryptocephala Kütz. & & & & & 5.5 \\
\hline Amphipleura pellucida (Kütz.) Kütz. & & & & & 5.8 \\
\hline Navicula cf. symmetrica Patr. & & & & & 4.0 \\
\hline
\end{tabular}

Only taxa and pools with mean rank abundances of 4.0 or greater (maximum rank $=7)$ are listed. $(n=10$, except Pool 7, where $n=2$ ). Pools for taxonomic analysis were chosen randomly

altered assemblage (ANOSIM2; $R=0.466$, $P=0.001)$, with less Gomphonema parvulum (rank $=5.4$ versus $6.3-7.0$ at upstream pools) and more Navicula cryptocephala Kütz and Amphipleura pellucida (Kütz.) Kütz., which are unattached 'boatshaped' taxa. This change in dominant taxa is consistent with the observed increase in settled fine sediment at the downstream site, which was directly below a low-water stream crossing used by cattle and farm vehicles.

Non-diatom algae were strongly dominated by filamentous algae, especially the chlorophytes Oedogonium sp. and Spirogyra sp., and the cyanobacterium Lyngbya sp. Non-filamentous soft algae were much less common and were not counted.

Filamentous algal composition did not differ among any of the different ground-rock and agar control treatments (ANOSIM2; $R=0.072, \quad P=0.135$ ). Graphical depiction of samples with NMDS showed no evidence of clustering based on rock substrate (Fig. 4).

Filamentous algal composition shifted downstream (ANOSIM2; $\quad R=0.314, \quad P=0.002 ; \quad$ Fig. 5). Oedogonium sp. and Lyngbya sp. co-dominated the three upstream sites, with ranks averaging greater than 6 of a maximum of 8 . In the two lower sites, Lyngbya remained a common taxon, but Oedogonium was largely replaced with another chlorophyte, Spirogyra sp.

\section{Discussion}

Streambeds often contain more than one type of rock, especially in watersheds with complex geologies. For example, the streambed of the East River, located in Gunnison County, Colorado near the Rocky Mountain Biological Station, is dominated by sandstones, black slate, and quartzite, but also includes at least 10 other types of rocks (Bergey and Cooper, unpublished data). Differences in algal biomass or assemblage composition among rock types in such stream beds would result in high spatial patchiness of benthic algae.

This study demonstrated that algal biomass was unaffected by the chemistries of different rock types, as tested using chlorophyll $a$ accrual on rockcontaining agar substrates-a design that excluded the confounding effects of rock roughness. In comparison to using whole rocks, powdered rock had a much higher area of rock surface and the constituents of the rocks were newly exposed, versus weathered in streambed stones. Thus, any direct effects of rock chemistry on algal biomass and composition should have been exaggerated; however no biomass effects were found, despite the wide range of tested rock chemistries (i.e., gypsum, serpentine, limestone, phosphorite, and a variety of silicates). The same conclusion was reached in an earlier version of this experiment that compared only two siliceous rock types (greywacke and schist) and powdered glass in a greenhouse experiment with recirculating channels (Bergey, 2005).

Rock chemistry had much less effect on algal assemblages than stream location. Diatoms are a speciose group and species vary in tolerances such that assemblage composition can vary with environmental conditions. Although replicates within rock types tended to cluster near each other in ordination, they did not form clusters that were distinguishable 

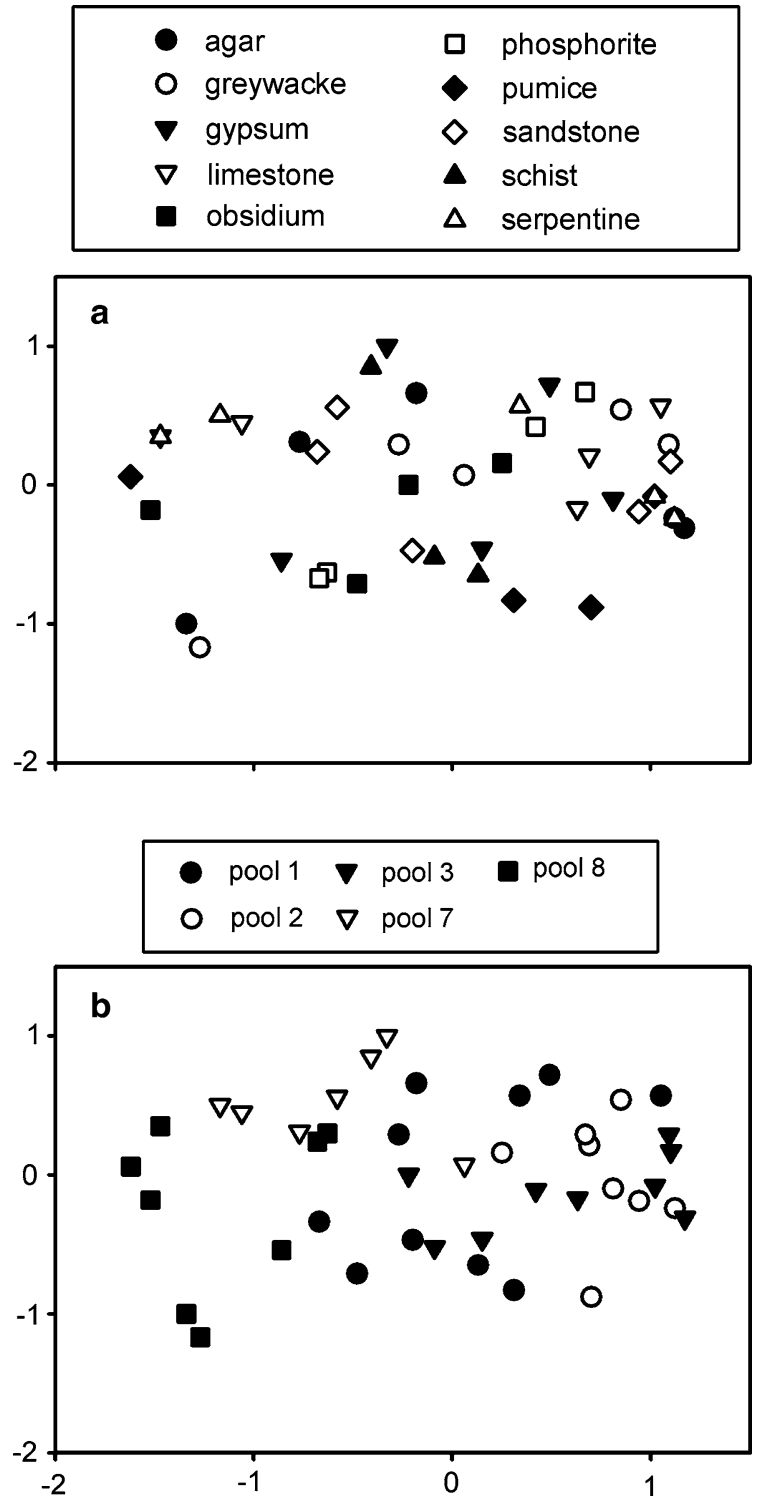

Fig. 4 Non-metric multidimensional scaling ordination of filamentous algal assemblages from agar-powdered rock substrates. Assemblages are coded by rock type (a) and by pool location (b). Stress $=0.13$

from clusters of other rock types. Diatom assemblages were also similar among most pools, except for the most downstream site that had more deposited fine sediment, and consequently, had more motile and fewer attached taxa. Filamentous algal composition showed no pattern among rock type; instead it showed a downstream substitution of Oedogonium sp. with Spirogyra sp.

In contrast to this study, which used powdered rocks, studies of algal colonization using whole rocks

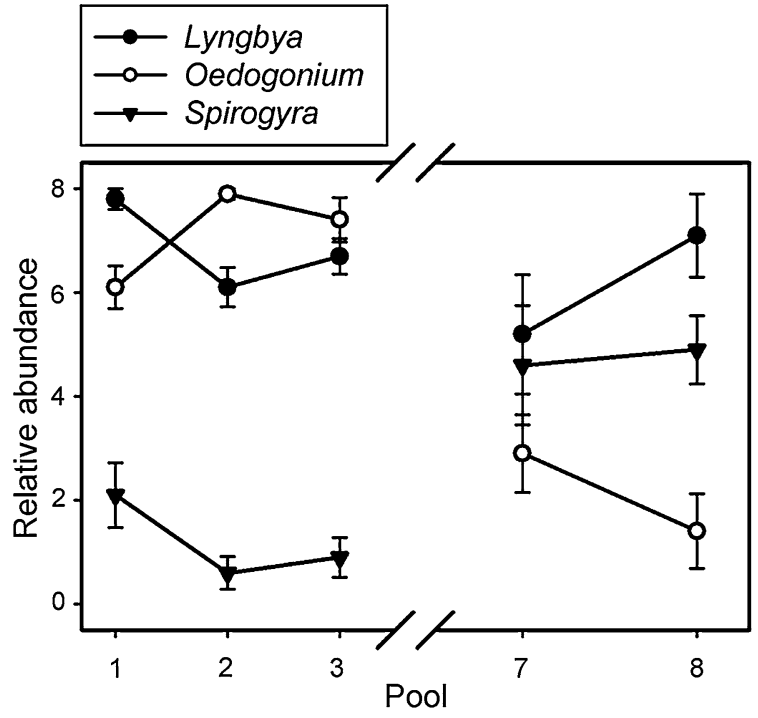

Fig. 5 Upstream (Pool 1) to downstream (Pool 8) patterns of relative abundance of the three dominant filamentous algae on substrates in Rock Creek. Missing pools were assayed for chlorophyll $a$ concentration only

have frequently shown differences in biomass accumulation and sometimes in algal composition among rock types. Rougher rocks accrue more algal biomass: coarse sandstone $>$ fine sandstone and siltstone (Antoine \& Benson-Evans, 1985), and pumice $>$ schist $>$ greywacke (Bergey, 2005). Blinn et al. (1980) followed algal colonization of sandstone, limestone, and basalt, and found that sandstone accumulated greater cell density during early colonization, but that after the first week, all substrates had similar cell densities. Sanson et al. (1995) and Bergey (2006) used different methods to quantify roughness, but both found a positive relationship between roughness and algal biomass. Green algae, both filamentous and non-filamentous taxa, may be more abundant on rough sandstone that on smoother rocks (Antoine \& Benson-Evans, 1985), possibly because of site selection by motile zoospores and other dispersal stages (e.g., Dudley \& D’Antonio, 1991). Differences in rock roughness may also influence habitat choice by invertebrates. Peckarsky \& Cowan (1995) found that some mayflies (Baetis bicaudatus Dodds and Ephemerella sp.) selected rougher granite while one mayfly taxon (Epeorus, sp., which is greatly flattened) preferred the smoother slate.

Although not specifically tested, researchers comparing algal accrual across rock types have 
suggested that physical features of rocks-roughness, porosity, and solubility-are more important for periphyton establishment and growth than substrate chemistry (Blinn et al., 1980; Antoine \& Benson-Evans, 1985). A similar conclusion was reached with biofilms and algae in marine habitats (Wells et al., 1989; Guidetti et al., 2004). Other examples can also be found. After a colonization study of six rock types, Luther (1976) constructed substrates with different-sized quartz grains, and based on algal colonization of these chemically equal substrates, concluded that surface texture was more important than substrate hardness or chemical composition, though these attributes were not tested. Similarly, granite slabs treated to make surfaces with different roughness differed in macroalgal cover; roughness also affected diatom microdistribution (Hutchinson et al., 2006). During aerial exposure in intertidal zones, wood and porous rocks, such as limestone, retain water and increase desiccation tolerance of exposed algae (Nienhuis, 1980).

Why are diatoms, which are physically associated with rock surfaces and the overlaying boundary layer, so little affected by stone chemistry? An explanation may be that diatoms (and possibly other algae) can take up dissolved chemicals but not chemicals bound in a rock matrix. Phosphorite, or rock phosphate, is used as a terrestrial soil fertilizer, but did not increase benthic algal biomass when tested in this study, despite the stream being phosphorus limited (as demonstrated by increased algal biomass in the Penriched nutrient diffusing substrates). When ground and applied to soil, the phosphorus in rock phosphate becomes available to plants only after it has dissolved (Bolland \& Gilkes, 1990), a process aided by low $\mathrm{pH}$, which may be locally caused by some soil microbes (Nahas, 1996; XiaoRong et al., 2003). Thus, rock phosphate, though used as a fertilizer, is not directly usable by plants and is an ineffective fertilizer in some soils (Bolland \& Gilkes, 1990). An additional consideration is that some dissolved chemicals must also be in a biologically active form. For example, nitrogen, which makes up $78 \%$ of air and occurs as a dissolved gas, is biologically inert to all but nitrogen fixers, which incorporate atmospheric nitrogen into compounds such as ammonia. Once fixed, nitrogen is widely used by organisms.

Nutrient diffusing substrates provide a solid surface for periphyton growth, but rely on the outward movement of dissolved nutrients. In making these substrates, dissolved, biologically available nutrients are added to agar and these nutrients leach from the agar into the overlaying water (Corkum, 1996). The material used as a substrate for periphyton growth varies and includes cellulose paper, walls of clay pots, and porous silica, all of which are permeable and allow nutrient passage. Pringle (1987) demonstrated that diatoms can capture and use both dissolved nutrients in the water column and nutrients diffusing from agar sources by adding nitrogen to agar and phosphorus to stream water.

Although no evidence of rock chemistry effects on periphyton biomass were found, the experimental design does not preclude all rock chemistry effects. Because biofilms may not have been in direct contact through the filter with the powdered rock, bioerosion of rock by components of the biofilm were likely limited in this experiment. Some cyanobacteria can chemically erode carbonates (e.g., limestone and coral rock), although it is unclear whether the cyanobacteria or their associated bacteria are the erosion agents (reviewed by Schneider \& Le Campion-Alsumard, 2007). This erosion increases rock micro-surface area, increasing dissolution by water, and increases mechanical erosion by algal grazers.

Scaling up, watershed geology influences steam periphyton (Biggs, 1995; Leland \& Porter, 2000; Weilhoefer \& Pan, 2006), but this effect may be from the dissolution of rocks by groundwater and surface waters rather than being a direct effect of chemical interactions between rocks and their associated algae. In groundwater, the dissolution of rocks by water is promoted by a high ratio of rock surface to water volume and a long water residence time. Dissolution rates vary with temperature, $\mathrm{pH}$, and rock type (Yadav et al., 2008).

These results indicate that the chemical composition of streambed stones is of little importance to stone-dwelling periphyton. This lack of chemical effect helps explain the similarity of algal biomass and assemblages among substrates as different as rock and wood (e.g., Townsend \& Gell, 2005; biomass and density: Sabater et al., 1998) and the success of using artificial substrates as surrogates for natural substrates in periphyton studies (e.g., Lowe \& Gale, 1980; Tuchman \& Stevenson, 1980; Lamberti $\&$ Resh, 1985). 
Acknowledgments Robert Turner ground the rocks, Russell Hobson helped make agar substrates, Michael Lee and Shane Jones helped with field work, and Michelle Collins kindly allowed access to the field site. Research funding was provided by a Faculty Enrichment Grant (College of Arts and Sciences, University of Oklahoma), Oklahoma EPSCoR, and NSF grant DEB-0447449. The Fulbright Foundation and University of Chiang Mai (Thailand) provided support during manuscript preparation.

\section{References}

Antoine, S. E. \& K. Benson-Evans, 1985. Colonisation rates of benthic algae on four different rock substrata in the River Ithon, Mid Wales. U.K. Limnologica 16: 307-313.

Bergey, E. A., 2005. How protective are refuges? Quantifying algal protection in rock crevices. Freshwater Biology 50: 1163-1177.

Bergey, E. A., 2006. Measuring the surface roughness of stream stones. Hydrobiologia 563: 247-252.

Biggs, B. J. F., 1995. The contribution of flood disturbance, catchment geology and land use to the habitat template of periphyton in stream ecosystems. Freshwater Biology 33: 419-438.

Blinn, D. W., A. Fredricksen \& V. Korte, 1980. Colonisation rates and community structure of diatoms on three different rock substrata in a lotic system. British Phycological Journal 15: 303-310.

Bolland, M. D. A. \& R. J. Gilkes, 1990. Rock phosphates are not effective fertilizers in Western Australian soils: a review of one hundred years of research. Fertilizer Research 22: 79-95.

Burkholder, J. M., 1996. Interactions of benthic algae with their substrata. In Stevenson, R. J., M. L. Bothwell \& R. L. Lowe (eds), Algal Ecology: Freshwater Benthic Ecosystems. Academic Press, San Diego, California: 253-297.

Campbell, R. S. \& I. F. Campbell, 1938. Vegetation on gypsum soils of the Jornada Plain, New Mexico. Ecology 19: $572-577$.

Cattaneo, A., G. Galanti, S. Gentinetta \& S. Romo, 1998. Epiphytic algae and macroinvertebrates on submerged and floating-leaved macrophytes in an Italian lake. Freshwater Biology 38: 725-740.

Corkum, L. D., 1996. Patterns of nutrient release from nutrient diffusing substrates in flowing water. Hydrobiologia 333: 37-43.

Dudley, T. L. \& C. M. D’Antonio, 1991. The effects of surface texture, grazing, and disturbance on macroalgal establishment in streams. Ecology 72: 297-309.

Guidetti, P., C. N. Bianchi, M. Chiantore, S. Schiaparelli, C. Morri \& R. Cattaneo-Vietti, 2004. Living on rocks: substrate mineralogy and the structure of subtidal rocky substrate communities in the Mediterranean Sea. Marine Ecology Progress Series 274: 57-68.

Hutchinson, N., S. Nagarkar, J. C. Aitchison \& G. A. Williams, 2006. Microspatial variation in marine biofilm abundance on intertidal rock surfaces. Aquatic Microbial Ecology 42: 187-197.
Jorgensen, E. G., 1957. Diatom periodicity and silicon assimilation. Dansk Botanisk Arkiv 18: 1-54.

Kruckeberg, A. R., 1954. The ecology of serpentine soils. III. Plant species in relation to serpentine soils. Ecology 35: 267-274.

Lamberti, G. A. \& V. H. Resh, 1985. Comparability of introduced tiles and natural substrates for sampling lotic bacteria, algae and macroinvertebrates. Freshwater Biology 15: 21-30.

Laugaste, R. \& M. Reunanen, 2005. The composition and density of epiphyton on some macrophyte species in the partly meromictic Lake Verevi. Hydrobiologia 547: 137-150.

Ledger, M. E. \& A. G. Hildrew, 1998. Temporal and spatial variation in the epilithic biofilm of an acid stream. Freshwater Biology 40: 655-670.

Leland, H. V. \& S. D. Porter, 2000. Distribution of benthic algae in the upper Illinois River basin in relation to geology and land use. Freshwater Biology 44: 279-301.

Lowe, R. L. \& W. F. Gale, 1980. Monitoring river periphyton with artificial substrates. Hydrobiologia 69: 235-244.

Luther, G., 1976. Fouling studies on natural stone substrates in the tidal zone of the North Sylt Wadden Sea: algae. Helgoländer Wissenschaftliche Meeresuntersuchungen 28: 318-351.

Matthaei, C. D., C. Guggelberger \& H. Huber, 2003. Local disturbance history affects patchiness of benthic river algae. Freshwater Biology 48: 1514-1526.

Nahas, E., 1996. Factors determining rock phosphate solubilization by microorganisms isolated from soil. World Journal of Microbiology and Biotechnology 12: 567-572.

Nienhuis, P. H., 1980. The epilithic algal vegetation of the SW Netherlands. Nova Hedwigia 33: 1-94.

Peckarsky, B. L. \& C. A. Cowan, 1995. Microhabitat and activity periodicity of predatory stoneflies and their mayfly prey in a western Colorado stream. Oikos 74: 513-521.

Pringle, C. M., 1987. Effects of water and substratum nutrient supplies on lotic periphyton growth: an integrated assay. Canadian Journal of Fisheries and Aquatic Sciences 44: 619-629.

Pringle, C. M., 1990. Nutrient spatial heterogeneity: effects on community structure, physiognomy, and diversity of stream algae. Ecology 71: 905-920.

Sabater, S., S. V. Gregory \& J. R. Sedell, 1998. Community dynamics and metabolism of benthic algae colonizing wood and rock substrata in a forest stream. Journal of Phycology 34: 561-567.

Sanson, G. D., R. Stolk \& B. J. Downes, 1995. A new method for characterizing surface roughness and available space in biological systems. Functional Ecology 9: 127-135.

Sartory, D. P. \& J. U. Grobbelaar, 1984. Extraction of chlorophyll $a$ from freshwater phytoplankton for spectrophotometric analysis. Hydrobiologia 114: 177-187.

Schneider, J. \& T. Le Campion-Alsumard, 2007. Construction and destruction of carbonates by marine and freshwater cyanobacteria. Journal of Experimental Biology 210: 91-96.

Stevenson, R. J., 1984. How currents on different sides of substrates in streams affect mechanisms of benthic algal 
accumulation. Internationale Revue der Gesamten Hydrobiologie 69: 241-262.

Townsend, S. A. \& P. A. Gell, 2005. The role of substrate type on benthic diatom assemblages in the Daly and Roper rivers of the Australian wet/dry tropics. Hydrobiologia 548: 101-115.

Tuchman, M. L. \& R. J. Stevenson, 1980. Comparison of clay tile, sterilized rock, and natural substrate diatom communities in a small stream in southeastern Michigan, USA. Hydrobiologia 75: 73-80.

Weilhoefer, C. L. \& Y. Pan, 2006. Diatom assemblages and their associations with environmental variables in Oregon Coast Range streams, USA. Hydrobiologia 561: 207-219.

Wells, J., E. J. Moll \& J. J. Bolton, 1989. Substrate as a determinant of marine intertidal algal communities at Smitswinkel Bay, False Bay, Cape South Africa. Botanica Marina 32: 499-502.
Whitton, B. A., 1975. River Ecology. Blackwell Scientific Publishers, Oxford, UK.

Wu, Z., P. Deng, X. Wu, S. Luo \& Y. Gao, 2007. Allelopathic effects of the submerged macrophyte Potamogeton malaianus on Scenedesmus obliquus. Hydrobiologia 592: 465-474.

XiaoRong, Z., L. QiMei \& B. G. Li, 2003. Relationship between rock phosphate solubilization and $\mathrm{pH}$ and organic acid production of microorganisms. Journal of Microbiology 23: 5-7.

Yadav, S. K., G. J. Chakrapani \& M. K. Gupta, 2008. An experimental study of the dissolution kinetics of calcite, dolomite, leucogranite and gneiss in buffered solutions at temperatures $25^{\circ} \mathrm{C}$ and $5^{\circ} \mathrm{C}$. Environmental Geology 53: 1683-1694. 